LOCAL WISDOM, 9 (1): 103-117, 2017
Local Wisdom Scientific Online Journal
ISSN: 2086-3764

\title{
“RUMAH LANTING” ARSITEKTUR VERNAKULAR SUKU BANJAR YANG MULAI PUNAH
}

\author{
Amar Rizqi Afdholy \\ Program Pasca Sarjana Arsitektur Lingkungan Binaan-Universitas Brawijaya \\ Jl. MT. Haryono, Malang 65145, Jawa Timur-Indonesia \\ Email: amayrizqi30@gmail.com
}

\begin{tabular}{|c|c|}
\hline & Abstrak \\
\hline $\begin{array}{l}\text { Kata Kunci: } \\
\text { Rumah Lanting, } \\
\text { Banjarmasin, } \\
\text { Sungai }\end{array}$ & $\begin{array}{l}\text { Rumah lanting adalah rumah venakular dari masyarakat suku Banjar yang berada di kota } \\
\text { Banjarmasin, Kalimantan Selatan. Menurut Mentayani (2010) bentuk rumah lanting yang } \\
\text { selaras dengan kondisi lingkungan berupa sungai dan penggunaan material, konstruksi, } \\
\text { hingga perilaku penghuni dalam menjalani kehidupan sehari-hari menunjukkan bahwa } \\
\text { rumah lanting adalah arsitektur vernakular daerah Kalimantan Selatan. Dilihat dari awal } \\
\text { terbentuknya rumah lanting, menurut Alfisyah (2014) rumah lanting muncul dikarenakan } \\
\text { adanya kegiatan perdagangan yang dilakukan oleh orang-orang perahu yang hidup } \\
\text { nomaden diatas sungai martapura. Kebutuhan akan hunian yang dapat menunjang } \\
\text { aktifitas mereka sebagai pedagang inilah yang kemudian memunculkan rumah lanting } \\
\text { yang terletak di tepian-tepian sungai kota Banjarmasin. Permasalahan yang diangkat dalam } \\
\text { kajian ini tentang kurangnya pengetahuan masyarakat terhadap tipe rumah vernakular } \\
\text { suku Banjar yaitu rumah lanting dan semakin berkurangnya jumlah rumah lanting yang } \\
\text { ada di kota Banjarmasin. Tujuan dari kajian ini menjelaskan tentang karakteristik rumah } \\
\text { vernakular suku Banjar yaitu rumah lanting dan faktor penyebab berkurangnya rumah } \\
\text { lanting di kota Banjarmasin. Metode yang dipakai pada kajian ini menggunakan metode } \\
\text { deskriptif kualitatif, data diperoleh dari hasil wawancara dan observasi langsung ke } \\
\text { lapangan. Dari hasil penelitian, faktor utama penyebab semakin berkurangnya rumah } \\
\text { lanting di kota Banjarmasin adalah perubahan aktifitas masyarakat yang dulunya } \\
\text { bergantung pada sungai sekarang sudah beralih ke daratan. }\end{array}$ \\
\hline
\end{tabular}

Keywords:

The Lanting House, Banjarmasin, River

\begin{abstract}
The Lanting house is vernacular house from Banjarism tribe which located in Banjarmasin, South Borneo. Mentayani (2010) said that the Lanting house form consistent with environment such as river, material used, construction, and the occupant's habit on doing daily life shows that The Lanting house is South Borneo's vernacular architecture. Seeing from the forming of The Lanting House, Alfisyah (2014) said that The Lanting House appeared because of trading activity by people who lived nomad on boat. The need of place to support their activity as seller makes them to build the lanting house which located on the river edges in Banjarmasin. The problem's points on this reseach are about knowledge of people in Banjarmasin to vernacular type house Banjarism tribe, The Lanting house, and decreasing The Lanting house's quantity in Banjarmasin. This research is aimed to explain about characteristic of the lanting house and causal factor of decreasing the lanting house's quantity. Method which is used in this research is descriptive qualitative, data are collected from interviews and direct observation to field. The result shows main factor of decreasing the lanting house's quantity in Banjarmasin is the changing of people activity which is people at past is rely on river and now change to street.
\end{abstract}

@ 2017 The Authors. Published by GKAK UNMER Malang

*Corresponding Author: amayrizqi30@gmail.com 


\section{“Rumah Lanting” Arsitektur Vernakular Suku Banjar Yang Mulai Punah \\ Amar Rizqi Afdholy}

\section{PENDAHULUAN}

Kota Banjarmasin adalah kota yang terdiri dari banyak sungai, kota Banjarmasin juga mendapat julukan sebagai "Kota Seribu Sungai", dikarenakan banyaknya sungai yang terdapat di kota Banjarmasin. Sekitar $40 \%$ wilayah dari kota Banjarmasin terdiri dari sungai besar dan sungai kecil yang saling berpotongan, salah satunya adalah sungai Martapura. Sungai Martapura merupakan sungai yang membelah kota Banjarmasin menjadi dua bagian dan sangat berperan dan menjadi urat nadi kehidupan masyarakat kota Banjarmasin. Menurut Mentayani (2016), Kota Banjarmasin bertumbuh dimulai dari permukiman-permukiman vernakular yang terbentuk di sepanjang sungainya. Permukiman vernakular tepian sungai di Banjarmasin merupakan permukiman yang tumbuh berdasar karakter dan unsur lokalitas. Karakter lokalitas tergambar dari budaya sungai dan struktur lahan basahnya.

Budaya sungai masyarakat kota Banjarmasin tersebut menghasilkan sebuah produk arsitektur berupa rumah lanting. Keberadaan rumah lanting di kota Banjarmasin merupakan wujud dari penyikapan dan respon masyarakat suku Banjarmasin terhadap kondisi lingkungannya. Menurut

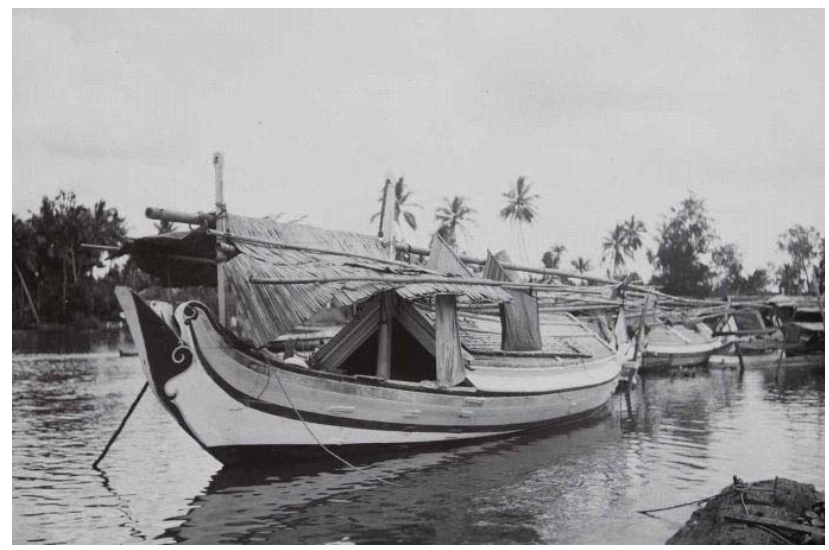

Gambar 1. Perahu Suku Banjar Zaman Dahulu. (Sumber: https://commons.wikimedia.org, 2016)
Rahman (2014), Rumah lanting merupakan istilah yang digunakan untuk menamai salah satu rumah tradisional Kalimantan Selatan. Rumah ini merupakan tipe rumah terapung yang berbahan utama kayu, sedangkan pada bagian bawah menggunakan batang kayu gelondongan atau drum sebagai pondasi untuk mengapungkan rumah ini. Rumah lanting merupakan satu-satunya rumah adat Banjar yang di bangun diatas air, rumah lanting bersifat fleksibel, karena dapat mengikuti perubahan pasang surut air sungai.

Pada awalnya rumah lanting merupakan rumah bagi para pedagang-pedagang yang berada di sungai, mereka memanfaatkan rumah lanting sebagai wadah untuk menunjang aktifitas mereka sebagai pedagang, selain sebagai tempat berdagang rumah lanting juga digunakan sebagai tempat tinggal bagi para pedagang. Menurut Alfisyah (2014),Pada masa awal terbentuknya masyarakat Banjar, sebagian orang Banjar masih ada yang tinggal secara nomaden di perahu-perahu mereka. Mereka memiliki mata pencaharian meramu hasil hutan dan menangkap ikan. Selain untuk memenuhi kebutuhan sendiri mereka juga menjual hasil hutan dan hasil tangkapan mereka. Aktifitas tukar menukar ini biasanya dilakukan antar

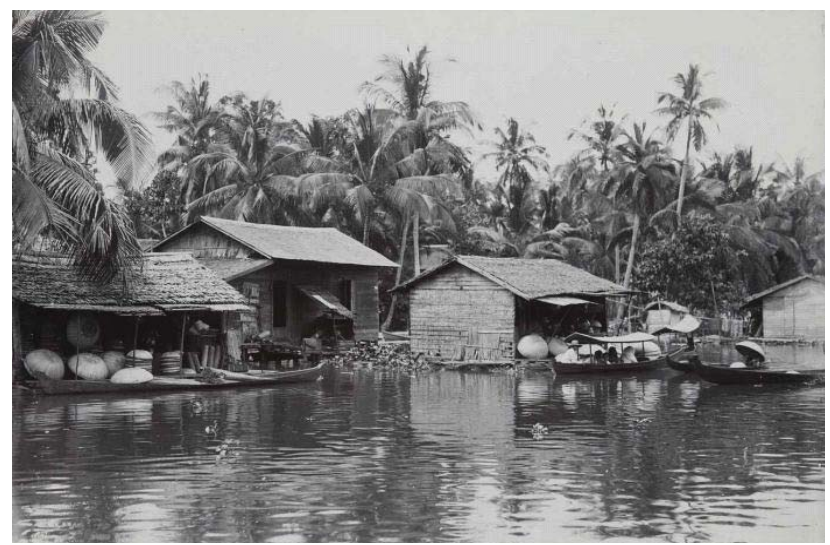

Gambar 2. Rumah Lanting Pada Zaman Dahulu. (Sumber: https://commons.wikimedia.org, 2016) 
perahu. Sisa-sisa kebudayaan ini masih bisa dilihat di beberapa tempat yang sekarang lebih dikenal dengan sebutan "pasar terapung" seperti di wilayah Kuin, siring sungai Martapura dan Lokbaintan Kabupaten Banjar. Untuk mempermudah akses dan mengurangi energi pada saat mengayuh perahu untuk berjualan maka beberapa orang perahu memusatkan aktifitas berjualan mereka pada suatu tempat, dan kemudian kumpulan dari orang-orang perahu yang berjualan pada suatu kawasan ini berkembang menjadi pasar. Menurut Alfisyah (2014), Sekitar abad ke-17 para orang-orang perahu ini sudah jarang terlihat, dan sebagai gantinya terdapat kumpulan rumah-rumah yang mengapung di atas sungai dengan fungsi sebagai tempat berjualan. Perkembangan populasi menyebabkan perahu tidak lagi dapat menampung keluarga yang semakin banyak.

Rumah lanting yang berada di tepian sungai sebagian besar dibangun oleh orang-orang perahu yang awalnya hidup di sungai, mereka membutuhkan hunian sebagai wadah aktifitas dan tempat tinggal bagi keluarganya. Menurut hasil wawancara dengan masyarakat, selain dibangun oleh orangorang yang dulunya tinggal di perahu, rumah lanting ini juga dibawa dari daerah luar daerah Banjarmasin, tepatnya daerah hulu sungai. Karena pada masa itu aktifitas perdagangan berkembang pesat di daerah sungai Banjarmasin, maka menarik minat para pedagang dari daerah luar Banjarmasin untuk berdagang di kawasan sungai Banjarmasin. Sifat rumah lanting yang fleksibel dan terapung diatas sungai sangat memudahkan untuk berpindah dari satu tempat ke tempat yang lain. Rumah lanting dibawa oleh pedagang dari Hulu Sungai dengan cara ditarik dengan menggunakan kapal atau bergerak tanpa ditarik mengikuti arus sungai. Para pedagang dari daerah Hulu Sungai ini kemudian berdagang di kawasan sungai Banjarmasin dengan menggunakan rumah lanting dan pada akhirnya menetap dengan cara menambatkan rumahnya di tepian sungai. Hal ini dibuktikan de- ngan banyaknya warga yang berasal dari daerah Hulu Sungai yang berada pada rumah lanting di lokasi penelitian.

Setelah kawasan tepian sungai ini menjadi pusat perdagangan maka banyak masyarakat yang membangun rumah-rumah lanting di tepian sungai, menurut Rahman (2014) Pada abad 18-19 perairan di kota Banjarmasin banyak dipenuhi oleh rumah-rumah lanting yang berderet mengikuti bentuksungainya. Hal ini menjadikan ciri khusus pada kota Banjarmasin dengan terdapat banyak rumah terapung di pinggir sungai.

Saat ini budaya berumah lanting di kota Banjarmasin sudah mulai ditinggalkan, Menurut Rahman (2014), kondisi ini salah satunya disebabkan karena adanya perubahan pola orientasi dari sungai ke darat serta terbatasnya ketersediaan bahan bangunan. Tidak dapat dipungkiri bahwa perkembangan jalur darat dan arus globalisasi yang cepat berdampak pada mulai ditinggalkannya rumah lanting sebagai bagian lokalitas tradisi budaya sungai masyarakat kota Banjarmasin. Identitas kota Banjarmasin dengan julukan kota seribu sungai dengan tradisi dan budaya sungai yang menjadi cikal bakal terbentuknya kota Banjarmasin sudah sangat ditinggalkan. Menurut data Identifikasi Rumah Lanting dari Dinas Tata Ruang, Cipta Karya dan Perumahan Kota Banjarmasin pada tahun 2013, jumlah rumah lanting yang tersisa di seluruh kota Banjarmasin sekitar 53 buah rumah saja. Dan semakin berkurang pada tahun 2016 dikarenakan adanya pembebasan lahan untuk pembangunan siring sungai Banjarmasin.

\section{METODE PEMBAHASAN}

Pembahasan dilakukan secara kualitatif dalam bentuk deskriptif analisis dari data dan referensi sumber yang didapatkan, yaitu dengan mendiskripsikan kemudian memberikan penafsiran-penafsiran dengan interpretasi rasional yang memadai terhadap fakta-fakta yang diperoleh. 


\section{“Rumah Lanting” Arsitektur Vernakular Suku Banjar Yang Mulai Punah}

Amar Rizqi Afdholy

Survei lapangan dilakukan untuk mengamati langsung keadaan rumah lanting di lokasi penelitian dan mengadakan wawancara pada beberapa orang masyarakat yang bertempat tinggal di rumah lanting pada daerah tersebut. Selanjutnya melakukan proses analisis pada karakteristik rumah lanting yang terdapat di lapangan dan memberikan kesimpulan mengenai faktor-faktor penyebab semakin berkurangnya jumlah rumah lanting.

\section{LOKASI PENELITIAN}

Kota Banjarmasin terletak pada $3^{\circ} 15^{\prime}$ sampai $3^{\circ} 22^{\prime}$ Lintang Selatan dan $114^{\circ} 32^{\prime}$ Bujur Timur, ketinggian tanah asli berada pada $0,16 \mathrm{~m}$ di bawah permukaan laut dan hampir seluruh wilayah digenangi air pada saat pasang. Kota Banjarmasin berlokasi daerah kuala sungai Martapura yang bermuara pada sisi timur Sungai Barito. Letak Kota Banjarmasin nyaris di tengah-tengah Indonesia. Kota Banjarmasin memiliki luas $98,46 \mathrm{~km}^{2}$ dan terbagi menjadi 5 kecamatan, yaitu Kecamatan Banjarmasin Tengah, Kecamatan Banjarmasin Utara, Kecamatan Banjarmasin Selatan, Kecamatan Banjarmasin Timur dan Kecamatan Banjarmasin Barat.(sumber:https://id.wikipedia.org/wiki/ Kota_Banjarmasin, 2016)

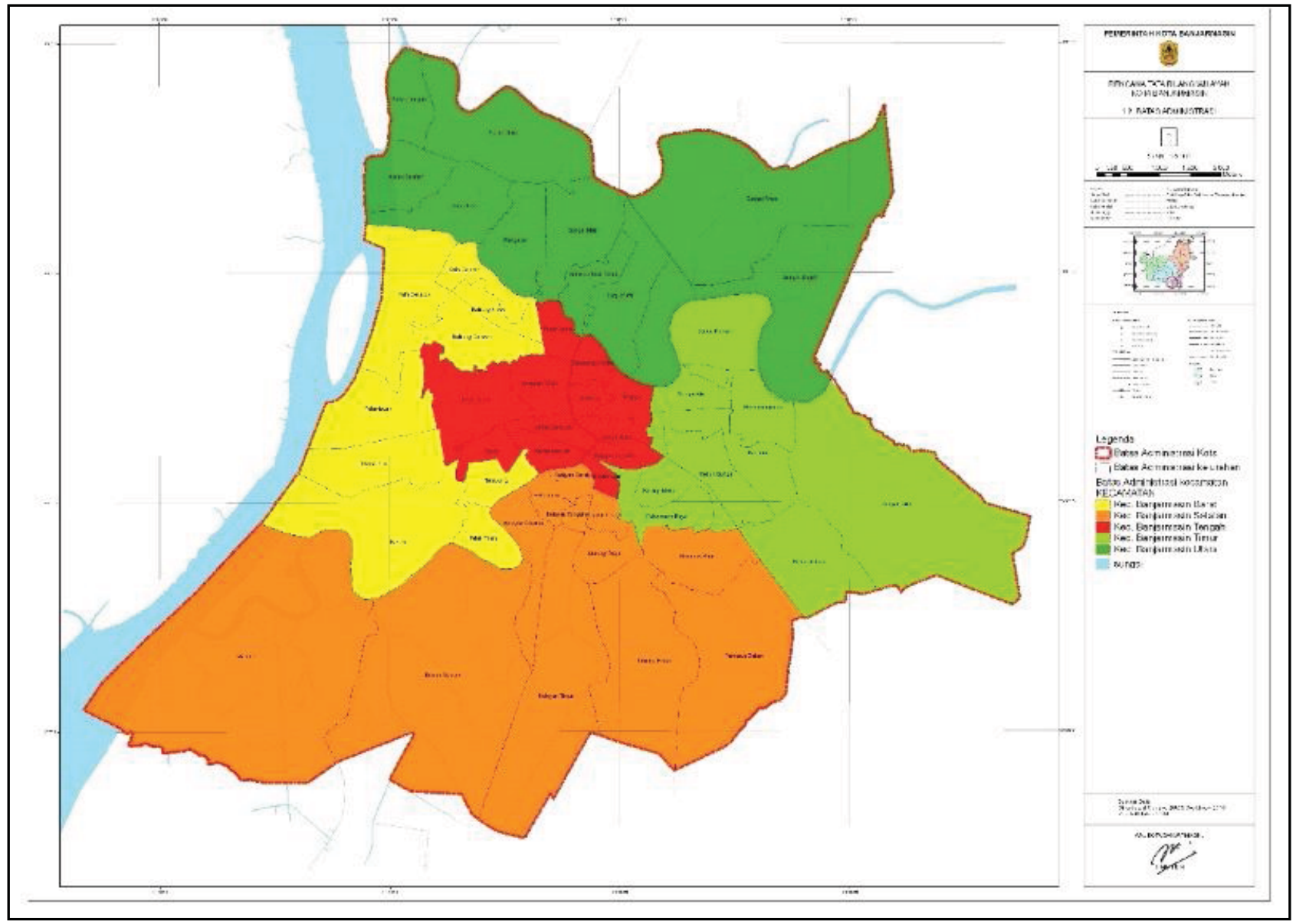

Gambar 3. Peta Kota Banjarmasin.

(Sumber: Dinas Cipta Karya dan Perumahan Kota Banjarmasin, 2015) 
Lokasi dari tapak difokuskan pada tepian sungai martapura yang berada di Kecamatan Banjarmasin Tengah, tepatnya di Kelurahan Seberang Mesjid, Pemilihan lokasi pada permukiman bantaran sungai Martapura yang berada di kelurahan seberang mesjid ini dikarenakan pada kawasan ini masih terdapat beberapa rumah vernakular Banjarmasin yaitu rumah lanting, sehingga kita dapat mengetahui tentang bentuk arsitektur vernakular masa lalu dan perubahan permukiman yang terjadi di kawasan ini.

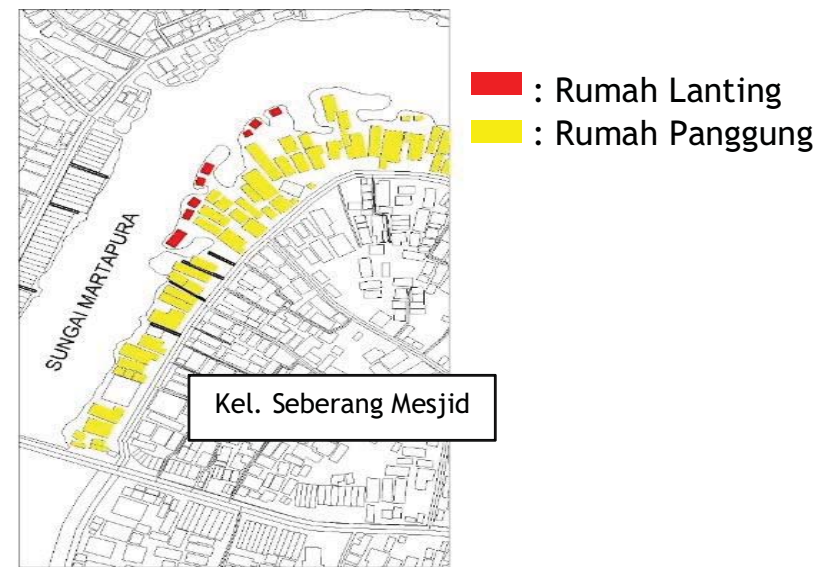

Gambar 4. Peta Permukiman Tepian Sungai Kel. Seberang Mesjid Sumber: Analisis Peneliti, 2016
Luas wilayah Kelurahan Seberang Mesjid adalah 75 ha. Batas wilayah Kelurahan Seberang Mesjid meliputi: sebelah utara berbatasan dengan sungai Martapura, sebelah selatan berbatasan dengan Kelurahan Gadang, sebelah timur berbatasan dengan sungai Martapura (Kecamatan Banjarmasin Utara), sebelah barat berbatasan dengan sungai Martapura (Kelurahan Pasar Lama).

Kawasan ini terbentuk oleh beberapa tipe rumah pinggiran sungai, berupa rumah lanting yang terletak di atas sungai, rumah panggung yang berada di tepian sungai dan rumah panggung yang berada di bantaran sungai. Tetapi pada penelitian ini difokuskan pada rumah yang terletak di atas sungai berupa rumah lanting.

\section{PEMBAHASAN}

\section{Karakteristik Rumah Lanting}

Dari hasil pengamatan di lapangan, diperoleh 9 (Sembilan) buah rumah lanting yang berada di kawasan studi dan selanjutnya dijadikan kasus untuk menjelaskan karakteristik dari rumah lanting tersebut. Hasil dari pengamatan tersebut ditemukan beberapa elemen pembentuk rumah lanting, yaitu sebagai berikut:

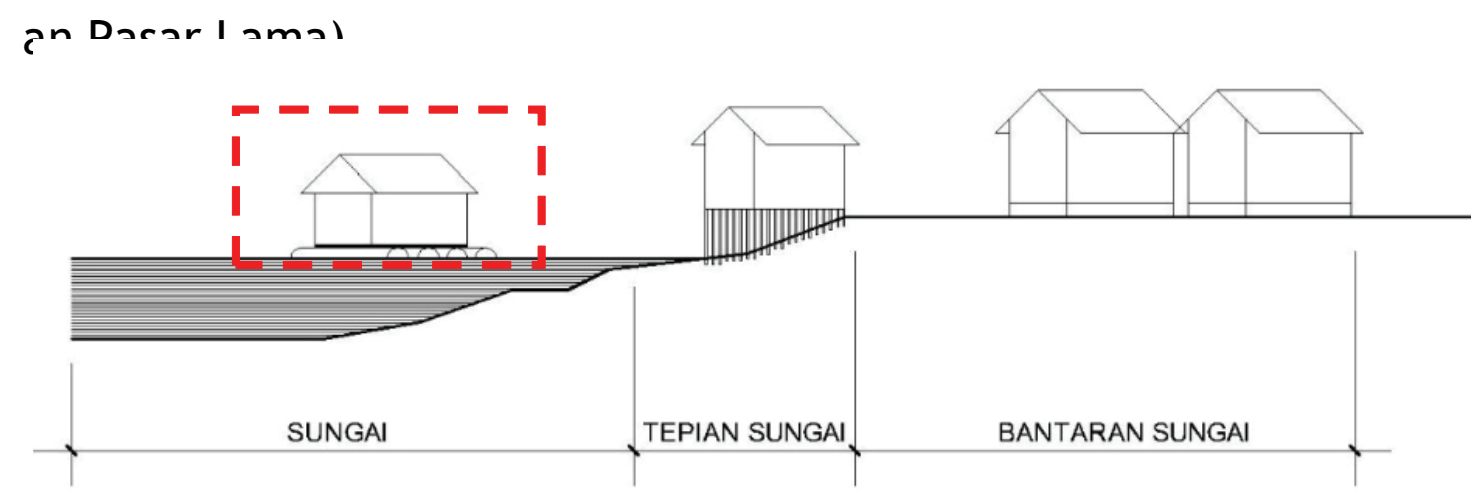

Gambar 5. Permukiman Tepian Sungai Kel. Seberang Mesjid

(Sumber: Analisis Peneliti, 2016) 
“Rumah Lanting” Arsitektur Vernakular Suku Banjar Yang Mulai Punah

Amar Rizqi Afdholy

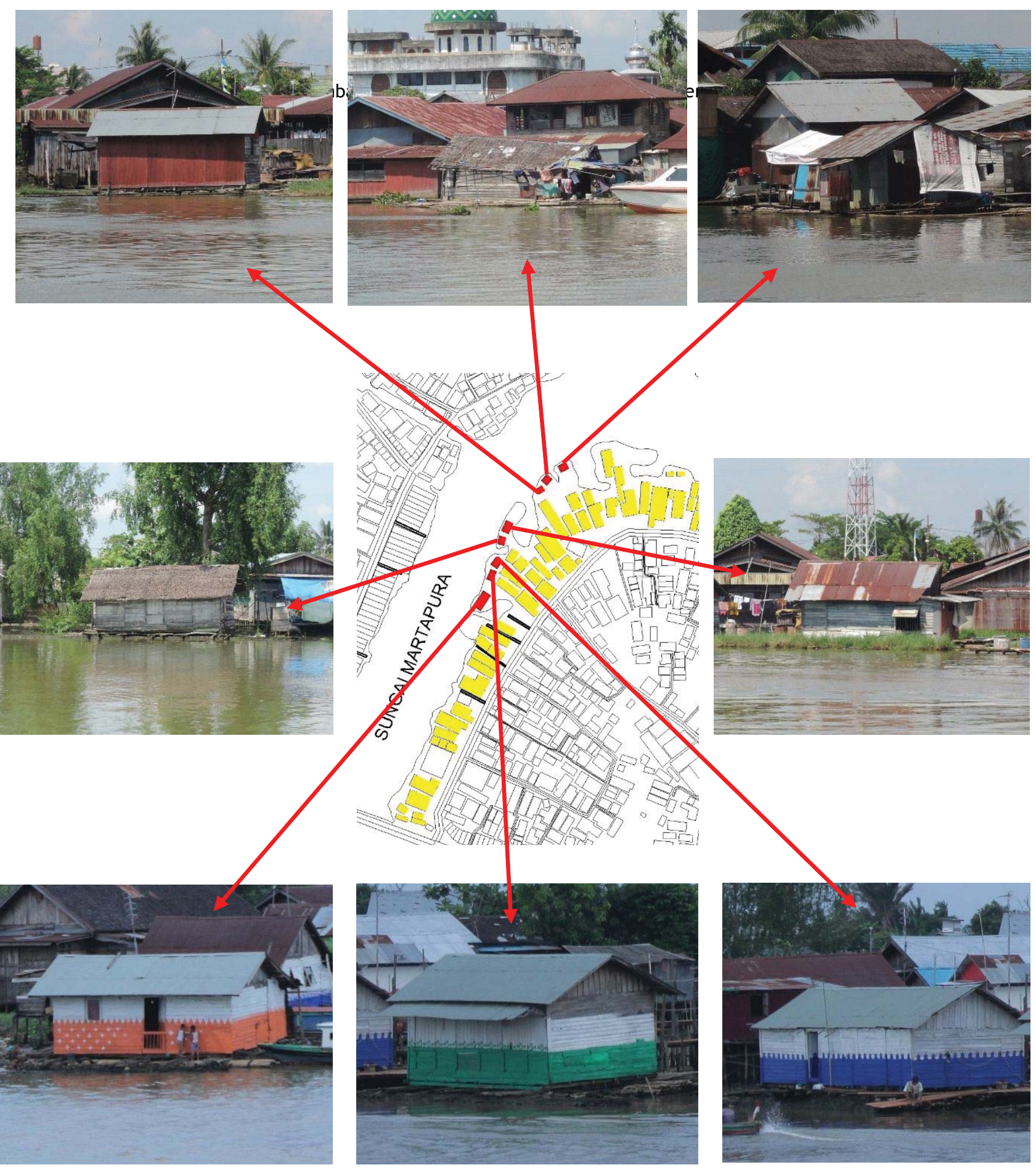

Gambar 6. Peta Persebaran Rumah Lanting (Sumber: Survey, 2016) 


\section{LOCAL WISDOM, Vol. 9 No. 2 Juli 2017}

Local Wisdom Scientific Online Journal

\section{A. Fasad Bangunan}

Dari hasil survey di lapangan, tampilan fasade bangunan rumah lanting terlihat sederhana tanpa dekorasi, berbentuk persegi panjang dengan ukuran relatif kecil, sekitar $20-40 \mathrm{~m} 2$ dengan tinggi rata-rata antara 2,5-3 $\mathrm{m}^{2} \mathrm{dan}$ mengapung di atas air. Bangunan ini bercirikan arsitektur tradisional Banjar, karena sebagian besar bahan material yang di pakai adalah kayu.
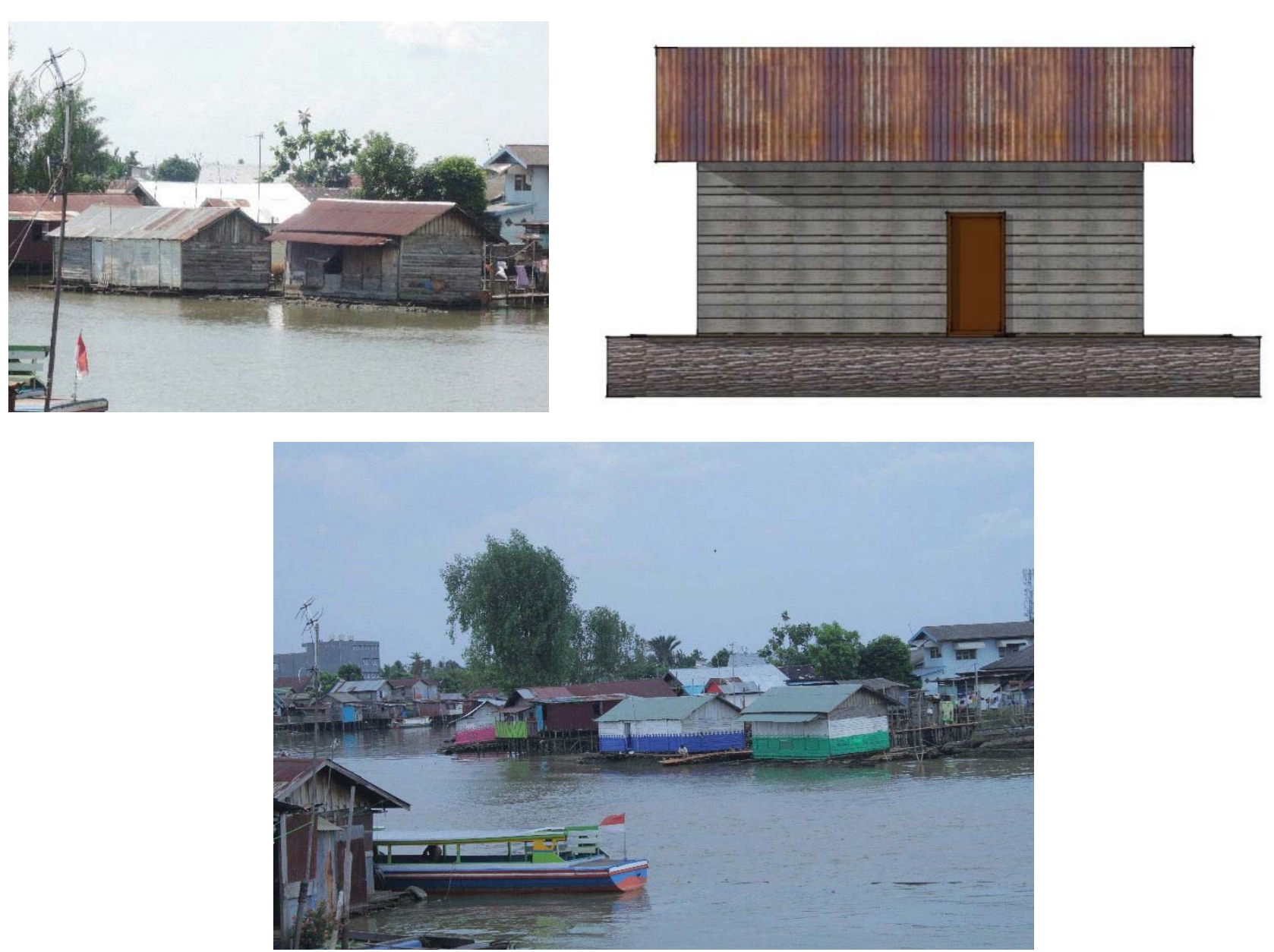

Gambar 7. Fasad Rumah Lanting (Sumber: survey Lapangan, 2016)

\section{B. Jarak Bangunan}

Terdapat jarak antar bangunan rumah lanting, pada rumah lanting jarak bangunan biasanya antara 3-5 meter, ruang yang terdapat antara rumah ini digunakan untuk meletakan jukung atau perahu milik penghuninya. Karena sebagian penghuni rumah lanting masih menggunakan sungai sebagai akses transportasinya untuk berdagang, maka mereka mempunyai jukung atau perahu sebagai alat transportasinya dan meletakannya di samping rumah. 


\section{"Rumah Lanting" Arsitektur Vernakular Suku Banjar Yang Mulai Punah \\ AmarRizqi Afdholy}
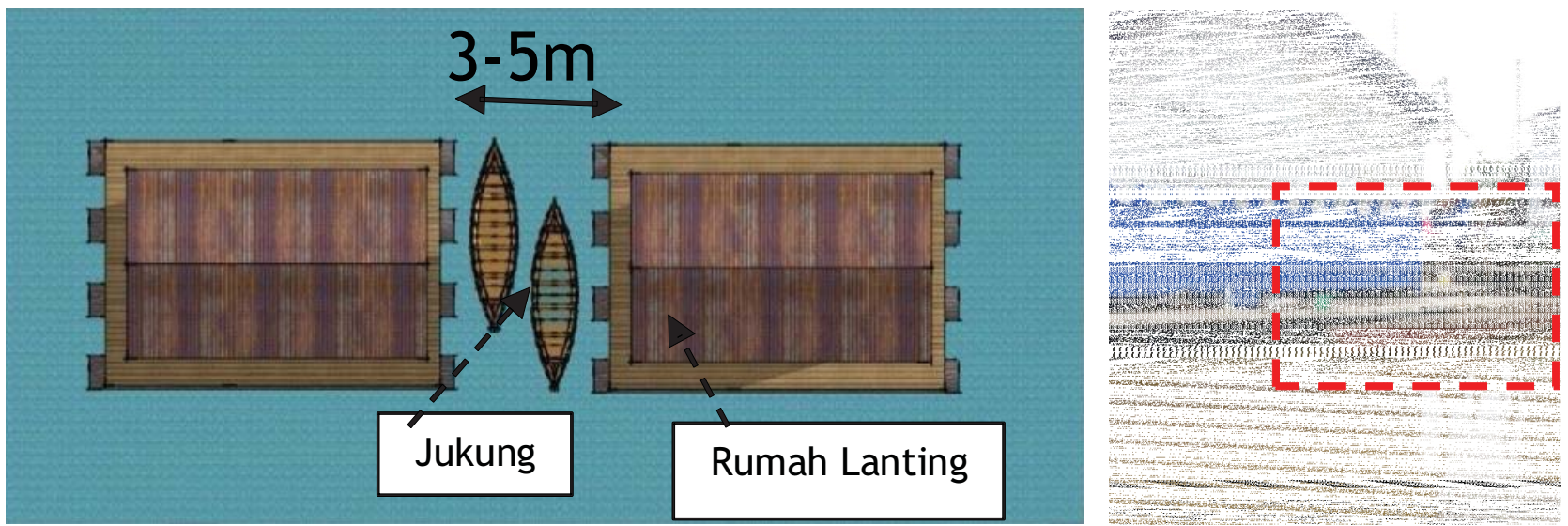

Gambar 8. Jarak Antar Rumah Lanting (Sumber: Analisis Peneliti, 2016)

\section{Ruang Dalam Bangunan}

Kondisi ruang dalam pada rumah lanting sangat sederhana, jarang sekali terdapat penyekat yang membatasi antar ruang. Rumah lanting saat ini hanya difungsikan sebagai tempat tinggal saja, oleh karena itu ruangan untuk berjualan sudah dihilangkan dan diganti dengan fungsi lain. Pada rumah lanting ukuran bangunan tidak terlalu besar, sekitar 20-40 $\mathrm{m}^{2}$, dengan tambahan teras berukuran kurang lebih $1 \mathrm{~m}^{2}$ mengelilingi bangunan

Pada beberapa rumah lanting umumnya hanya terdapat 2-3 ruang saja, yaitu ruang utama yang berfungsi sebagai tempat tidur pada malam hari, sebagai ruang keluarga di saaat saat santai, atau ruang tamu jika ada tamu yang dating, dan ruang pelayanan, seperti dapur untuk memasak atau menyiapkan bahan makanan. Biasanya pembatas antar ruang hanya disekat dengan prabot saja, contohnya lemari yang membatasi antara ruang tidur dengan dapur, dan ruang keluarga yang juga berfungsi sebagai ruang tamu. Sedangkan untuk keperluan MCK sepenuhnya dilaksanakan di luar rumah tepatnya di pelataran. Khusus untuk buang air besar mereka hanya perlu membangun dinding sederhana untuk melindungi dari pandangan orang, ada pula beberapa rumah lanting yang tidak memiliki toilet, sehingga mereka menggunakan jamban atau wc umum yang terletak di sekitar rumah mereka.

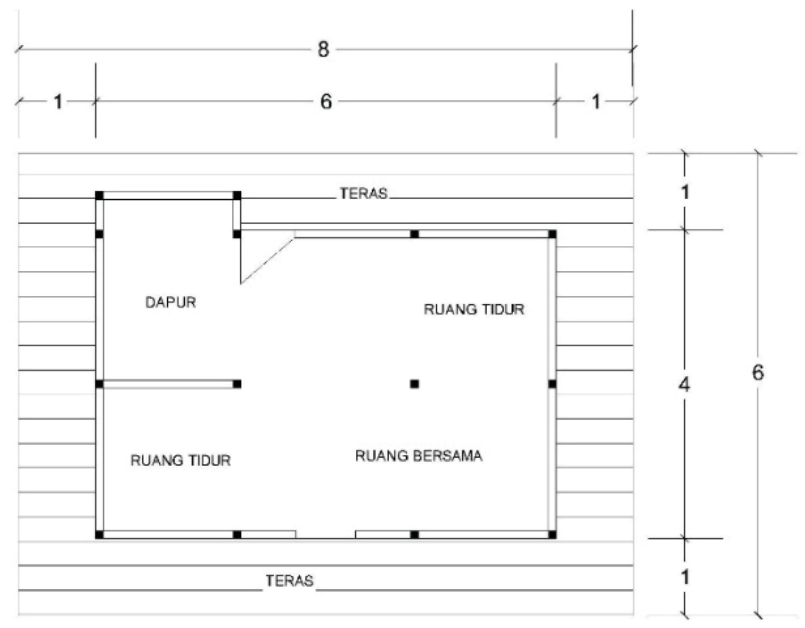

Gambar 9. Denah Rumah Lanting (Sumber: Analisis Peneliti, 2016) 
LOCAL WISDOM, Vol. 9 No. 2 Juli 2017

Local Wisdom Scientific Online Journal
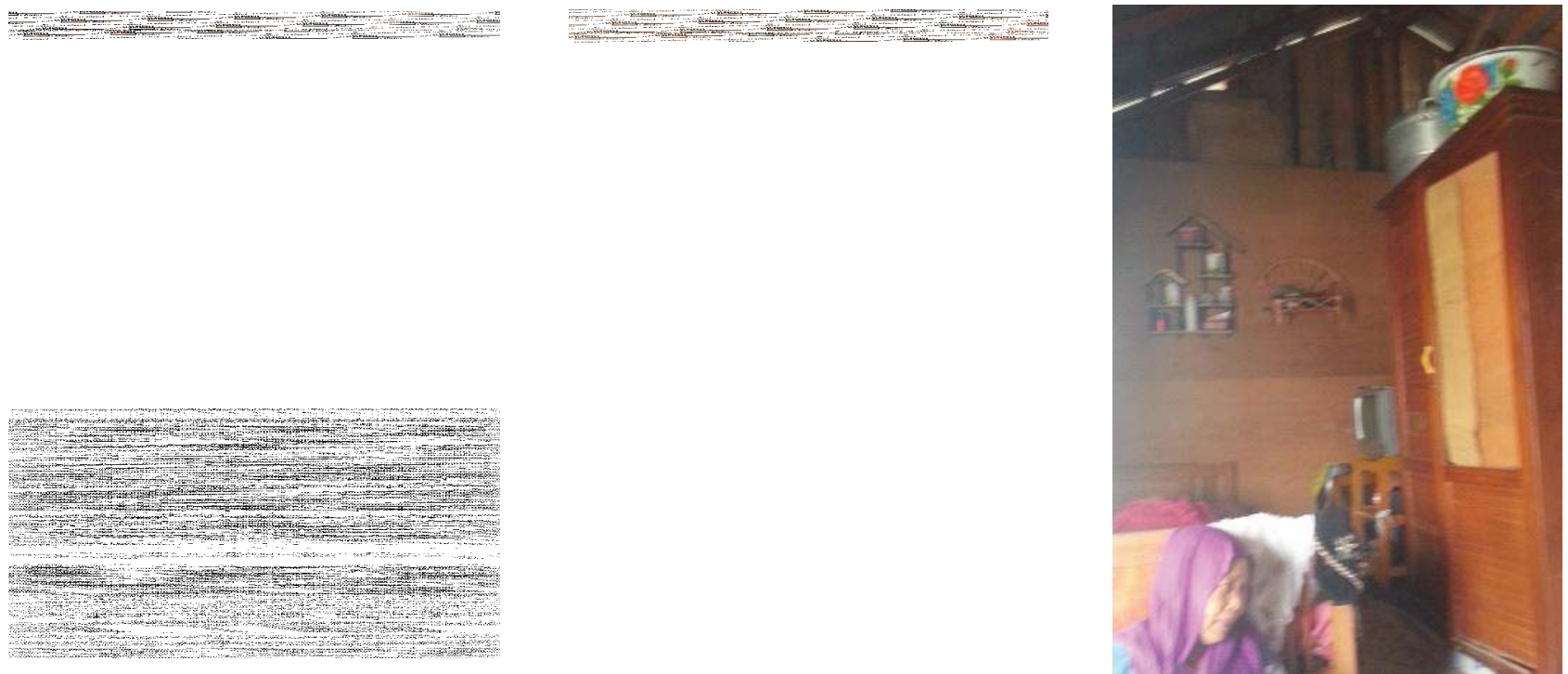

Gambar 10. Kondisi Ruang Dalam Rumah Lanting (Sumber: Survey Lapangan , 2016)

\section{Konstruksi Bangunan}

\section{- Bagian Atap Bangunan}

Pada bagian atap rumah lanting menggunakan atap pelana ini dikarenakan atap pelana merupakan konstruksi atap yang ringan dan sederhana, dengan menggunakan material kayu ringan seperti kayu lanan. Penggunaan material dan jenis atap ini agar dapat mengurangi beban pada pondasi. Adapun material penutup atap yang digunakan pada kawasan ini kebanyakan memakai penutup atap seng, walaupun masih ada yang menggunakan penutup atap dari daun rumbia.
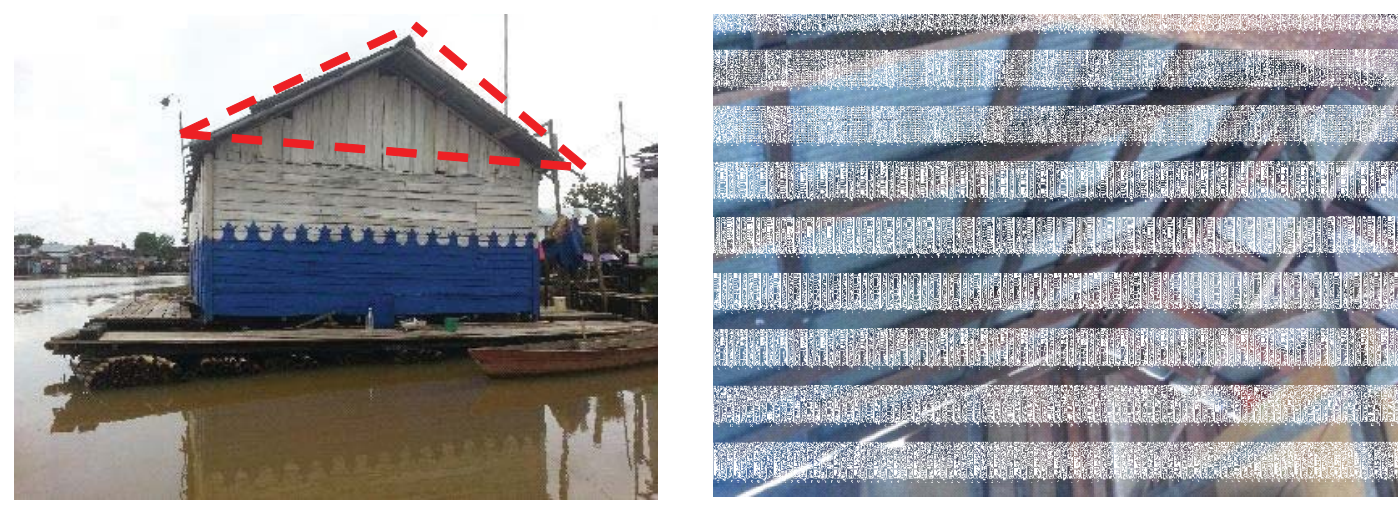

Gambar 11. Struktur Atap Rumah Lanting

(Sumber: Survey Lapangan, 2016) 

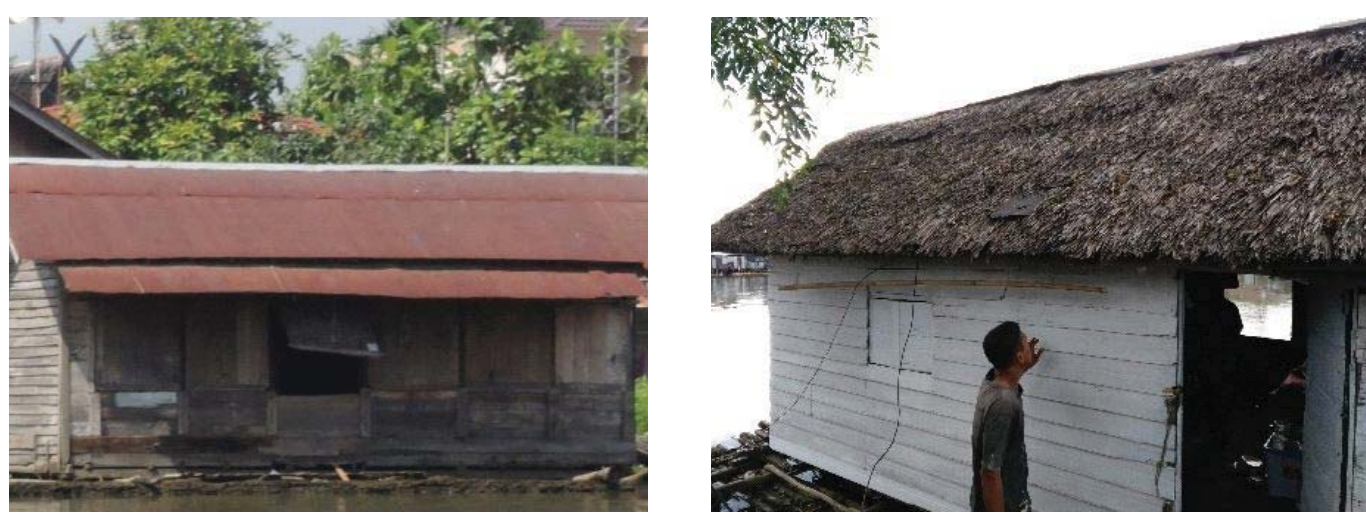

Gambar 12. Jenis Penutup Atap Rumah Lanting

(Sumber: Survey Lapangan, 2016)

\section{- Bagian Badan Bangunan}

Badan bangunan juga dibangun dengan bahan-bahan dan konstruksi yang sangat dikenal masyarakat. Struktur bangunan merupakan struktur rangka yang terbuat dari konstruksi kayu ulin, dengan penutup dinding kayu jenis lanan, pemasangan kayu pada dinding ini dipasang dengan cara disusun bertumpuk, karena untuk menghindari masuknya air pada saat hujan.
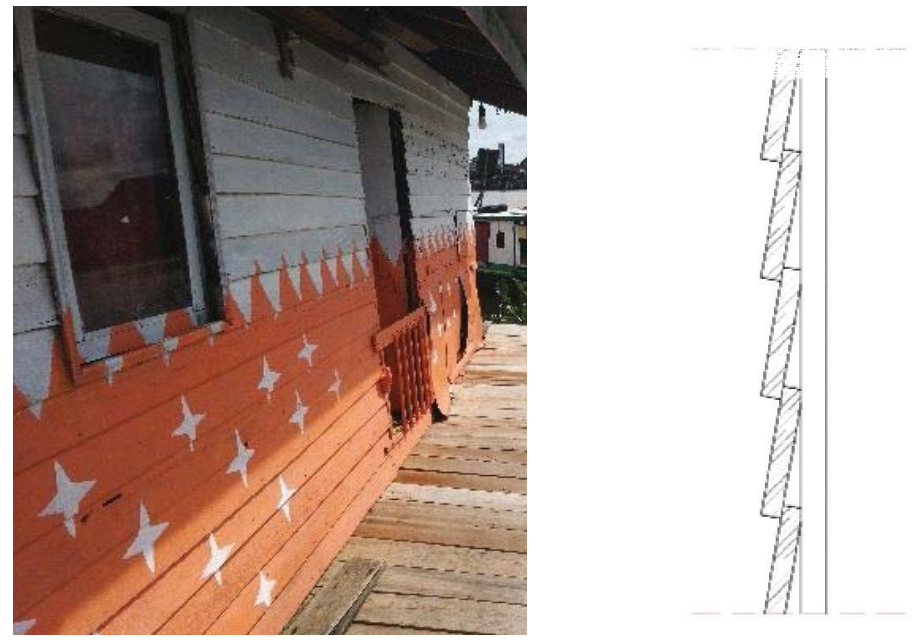

Gambar 13. Dinding Rumah Lanting

(Sumber: Survey Lapangan, 2016) 


\section{- Bagian Pondasi Bangunan}

Pondasi pada rumah lanting ini berfungsi sebagai penumpu beban dan juga sebagai alat pengapung untuk rumah lanting. Karena rumah ini dibangun di atas air maka diperlukan alat pengapung berupa kayu gelondongan, material ini dahulu masih mudah di dapatkan dikarenakan Kalimantan memiliki potensi kayu yang sangat melimpah. Kayu gelondongan ini biasanya berukuran diameter 0,8 - $1 \mathrm{~m}^{2}$. Tetapi sekarang kayu gelondongan sudah jarang ditemukan, sehingga digantikan dengan bambu.

Ada dua cara penggantian pondasi baru yang berupa bambu pada rumah lanting, yang pertama adalah dengan cara mengganti sebagian dan yang kedua adalah dengan cara mengganti seluruh pondasi kayu gelondongan dengan pondasi bambu. Pertimbangan cara penggantian pondasi ini dilihat dari kondisi kayu gelondongan pada rumah lanting itu sendiri. Semakin parah kerusakan pada kayu gelondongan, semakin berkurang pula daya tahan untuk mengapungkan bangunan. Kayu gelondongan yang masih terdapat pada rumah lanting di lokasi penelitian, sebagian besar masih asli dan sudah berumur lebih dari 50 tahun, sesuai dengan umur bangunannya.

Sebagai bahan pengganti kayu gelondongan, ternyata bambu mempunyai kekurangan dalam hal ketahanan. Menurut hasil wawancara, mereka mengeluhkan akan penggantian bambu yang harus rutin dilakukan, ketahanan pondasi bambu ini kurang lebih mampu bertahan selama dua tahun, sehingga perlu dilakukan penggantian pada pondasi tersebut. Jumlah bambu yang dipakai untuk dapat menahan beban rumah lanting ini menggunakan 80 bambu pada bagian belakang bangunan dan 100 bambu pada bagian depan bangunan.

Diatas pondasi ini terdapat sloof dan gelagar serta lantai yang menghubungkan dengan badan bangunan, material yang digunakan pada bagian ini menggunakan kayu ulin. Penggunaan bahan ulin ini disebabkan kayu ulin memiliki tingkat kekuatan dan keawetan yang sangat baik. Kayu ulin dikenal tahan terhadap air dan tahan terhadap serangan serangga kayu.

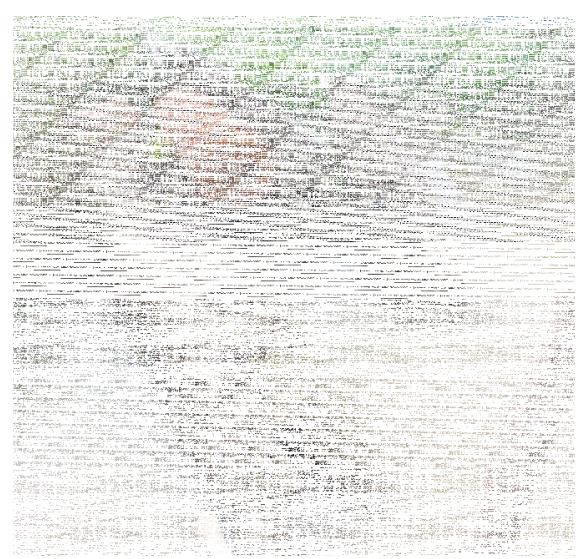

Gambar 14. Contoh Kayu Gelondongan yang Sudah Rusak (Sumber: Survey Lapangan , 2016)

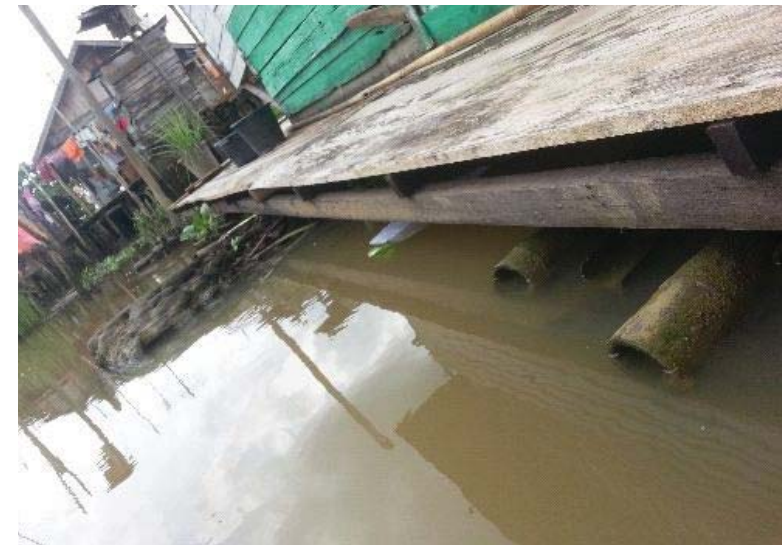

Gambar 15. Contoh Bangunan Dengan Pondasi Kombinasi Kayu Gelondongan dan Bambu (Sumber: Survey Lapangan , 2016) 


\section{"Rumah Lanting" Arsitektur Vernakular Suku Banjar Yang Mulai Punah \\ Amar Rizqi Afdholy}

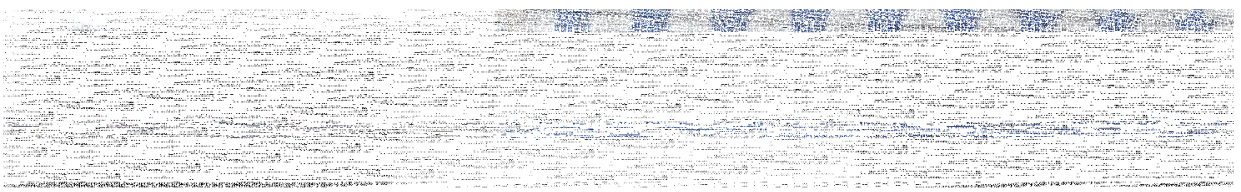

Gambar 16. Contoh Bangunan Dengan Pondasi Bambu

(Sumber: Survey Lapangan , 2016)

\section{E. Kenyamanan Termal Pada Rumah Lanting}

Kota Banjarmasin beriklim tropis dimana angin muson barat bertiup dari Benua Asia melewati Samudera Hindia menimbulkan musim hujan, sedangkan angin dari Benua Australia adalah angin kering yang berakibat adanya musim kemarau. Curah hujan yang turun rata-rata per tahunnya adalah kurang lebih $2.400 \mathrm{Mm}$ dengan fluktuasi tahunan berkisar antara 1.600-3.500 Mm, jumlah hari hujan dalam setahun kurang lebih 150 hari dengan suhu udara yang sedikit bervariasi sekitar $26^{\circ} \mathrm{C}$. Kota Banjarmasin termasuk wilayah yang beriklim tropis. Angin Muson dari arah Barat yang bertiup akibat tekanan tinggi di daratan Benua Asia melewati Samudera Hindia menyebabkan terjadinya musim hujan, sedangkan tekanan tinggi di Benua Australia yang bertiup dari arah Timur adalah angin kering pada musim kemarau. Hujan lokal turun pada musim penghujan, yaitu pada bulan-bulan November - April. Dalam musim kemarau sering terjadi masa kering yang panjang. Curah hujan tahunan rata-rata sampai $2.628 \mathrm{~mm}$ dari hujan pertahun 156 hari. Suhu udara rata-rata sekitar 25o C - 38o C dengan sedikit variasi musiman. Fluktuasi suhu harian berkisar antara 74$91 \%$ sedangkan pada musim kemarau kelembabannya rendah yaitu sekitar 52\% yang terjadi pada bulan-bulan Agustus, September dan Oktober. (https://id.wikipedia.org/wiki/Kota_ Banjarmasin).

Rumah lanting merupakan rumah yang terapung diatas air, hal ini tentunya berpengaruh dari faktor kenyamanan penghuni yang berada di dalamnya. Menurut Toding(2014), semakin tinggi permukaan lantai bangunan dari tanah maka kelembaban rata-rata semakin berkurang, semakin dekat lokasi rumah dengan bidang air/ sungai, makakelembabanya semakin tinggi. Hal ini membuktikan bahwa rumah lanting memeiliki kelembababn yang tinggi dikarenakan penempatan rumah lanting ini berada diatas sungai atau air. Pemilihan material pada rumah lanting ini sangat berpengaruh pada kondisi ruang dalam rumah lanting.

Material pembentuk rumah lanting didominasi oleh material kayu, penggunaan material kayu pada dinding bangunan rumah lanting ini sangat berperan untuk menurunkan kelembaban, pemasangan dinding kayu secara horizontal dan terdapat celah atau rongga antar papan kayu dapat 
berfungsi sebagai celah untuk masuknya udara, hal ini dapat menurunkan kelembaban didalam rumah. Selain dinding, lantai juga terbuat dari susunan papan-papan kayu ulin. Sama halnya seperti dinding, terdapat pula rongga antar papan yang berfungsi sebagai masuknya udara dari bawah rumah. Dalam bangunan pada daerah iklim tropis untuk menurunkan perpindahan panas dalam bangunan hanya mengandalkan system ventilasi alami.

elembaban, pemasangan
ara horizontal dan terdapat
a antar papan kayu dapat
ai celah untuk masuknya
at menurunkan kelembaban
Selain dinding, lantai juga
nan papan-papan kayu ulin.
erti dinding, terdapat pula
pan yang berfungsi sebagai

Menurut Toding(2014), keadaan temperatur efektif pada rumah lanting dimana pada rentan waktu pagi dalam kondisi Hangat Nyaman, Siang hari dalam kondisi Panas, dan sore - malam hari dalam kondisi Hangat Nyaman. Kondisi panas pada siang hari ini dikarenakan kondisi Banjarmasin yang cukup panas pada siang hari dan penggunaan material seng pada penutup atap bangunan.

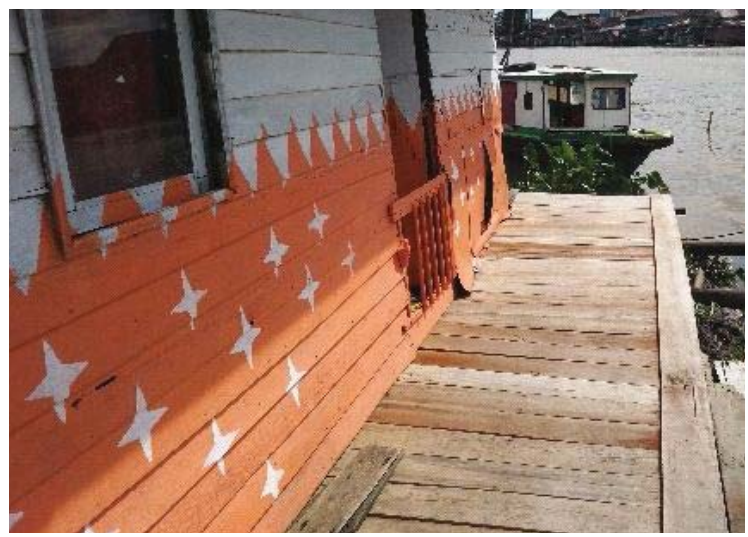

Gambar 17. Material Atap, Dinding Dan Lantai Yang Mempengaruhi Kenyamanan Pada Rumah Lanting (Sumber: Survey Lapangan , 2016)

\section{Faktor Penyebab Berkurangnya}

\section{Rumah Lanting}

Cara berhuni masyarakat Banjar yang kental dengan budaya kehidupan sungai tergambar pada kehidupan di rumah lanting. Rumah lanting awalnya bukan ditujukan sebagai hunian melainkan sebagai shelter atau toko terapung yang dibawa dari arah hulu sungai memasuki pasar terapung di kawasan Kota Banjarmasin. Menurut Mentayani (2016), Perkembangan infrastruktur darat yang lebih dominan menjadi salah satu penyebab berubahan basis hunian sungai ke darat. Inilah faktor utaman yang menyebabkan berkurangnya rumah lanting. Perkembangan zaman yang terjadi mengakibatkan hunian sungai yaitu rumah lanting semakin berkurang. Kemampuan ekonomi dan kemapanan seseorang menyebabkan keinginan untuk hidup yang lebih layak dengan membangun hunian mereka di daratan. Seiring berjalannya waktu sarana dan prasarana yang semakin lengkap, seperti dibangunanya jalan darat dan model transportasi darat yang beragam, menjadikan pola hidup masyarakat yang tadinya bermukim dan beraktifitas di tepian sungai berubah menjadi kedarat.

Dari hasil wawancara terhadap penghuni rumah lanting, didapatkan beberapa faktor yang menyebabkan berkurangnya jumlah rumah lanting pada kawasan ini, yaitu:

- Penghuni lama menjual rumah lanting tersebut.

- Rumah lanting dibongkar dan materialnya dijadikan bahan untuk membuat rumah di daratan.

- Berpindah tempat dan rumah lanting tersebut dibawa ketempat tujuannya.

- $\quad$ Rumah sudah rusak dan tidak layak huni. 


\section{“Rumah Lanting” Arsitektur Vernakular Suku Banjar Yang Mulai Punah}

Amar Rizqi Afdholy

- Ketidak mampuan pemilik rumah untuk memperbaiki rumah lanting, sehingga rumah lanting dibiarkan terbengkalai kemudian hancur.

Hampir semua penghuni rumah lanting merupakan masyarakat dengan ekonomi menengah kebawah, ini yang menjadikan kondisi rumah lanting tidak terlalu diperhatikan. Selain kondisi ekonomi penghuni, umur bangunan rumah lanting ini kebanyakan sudah lebih dari 50 tahun. Kondisi ini pula yang menyebabkan daya tahan bangunan rumah lanting ini sudah mulai berkurang, tanpa adanya perbaikan yang rutin tidak akan mungkin rumah lanting ini bisa bertahan lama.

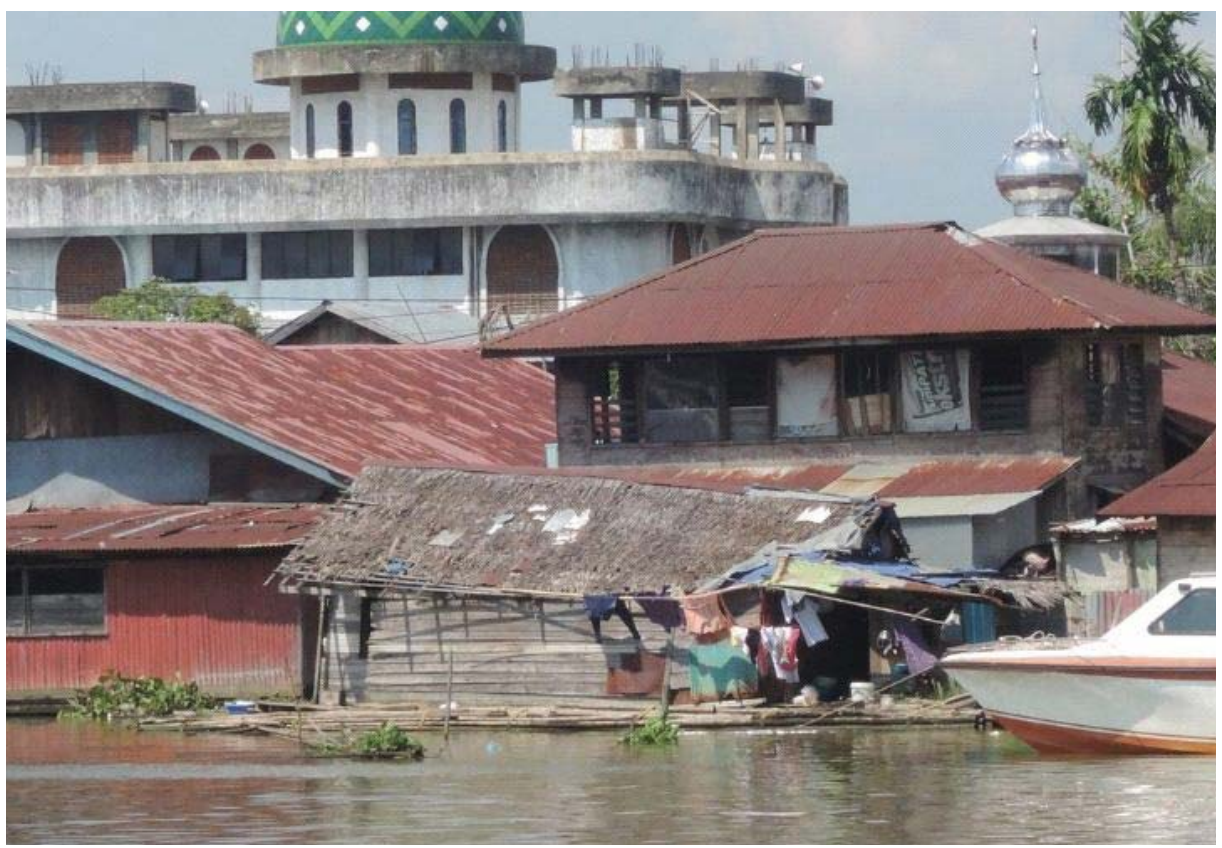

Gambar 17. Rumah Lanting Yang Sudah Rusak

(Sumber: Survey Lapangan , 2016)

\section{KESIMPULAN}

Rumah lanting merupakan hasil dari penyikapan masyarakat terhadap kondisi lingkungan kota Banjarmasin yang didominasi oleh keberadaan sungai. Kehadiran rumah lanting dianggap sebagai awal mula peradaban Banjar dan merupakan identitas kota Banjarmasin sebagai kota sungai. Karakteristik permukiman di tepian sungai Martapura dari segi hunian masih bercirikan kekhasan dari bangunan Banjar dengan menggunakan bahan kayu ulin yang menjadi kekhasan bangunan Banjar. Namun terjadi perubahan yang sangat men- colok pada tipe bangunan yang ada di tepian sungai ini, rumah lanting yang merupakan rumah vernakular kota Banjarmasin sekarang sudah terancam punah dan jarang ditemukan. Sekarang tipe bangunan rumah lanting ini telah digantikan dengan rumah-rumah yang berada di daratan, ini disebabkan karena perkembangan infrastruktur darat yang lebih dominan, aktifitas masyarakat yang dulunya menggunakan sungai sekarang berpindah ke darat, sehingga menyebabkan semakin berkurangnya jumlah rumah lanting yang berada di kota Banjarmasin. 


\section{LOCAL WISDOM, Vol. 9 No. 2 Juli 2017}

Local Wisdom Scientific Online Journal

\section{REKOMENDASI}

Dari hasil pembahasan dan kesimpulan yang telah diuraikan, diperoleh gambaran mengenai karakteristik permukiman di tepian sungai Martapura yang berupa rumah lanting. Rekomendasi yang dikemukakan dari pembahasan tersebut berkenaan tentang perlu adanya pelestarian pada bangunan rumah lanting yang mulai hilang di kota Banjarmasin, bangunan dengan arsitektur vernakular dari budaya sungai Banjarmasin ini perlu untuk dipertahankan, sehingga pada nantinya bangunan ini terhindar dari kepunahan dan dapat bermanfaat bagi generasi yang akan datang. Tindakan pelestarian ini dapat silakukan dengan cara rekonstruksi, yaitu dengan membangun kembali rumah lanting yang telah rusak dan mengganti material bangunan sekaligus melakukan perkuatan terhadap struktur yang melemah atau rusak dan selanjutnya dilakukan revitalisasi dengan melakukan pengembangan rumah lanting yang salah satunya mengoptimalkan fungsi rumah lanting sebagai objek wisata di kota Banjarmasin.

\section{DAFTAR PUSTAKA}

Alfisyah. (2014) Evolusi Pola Pemukiman Orang Banjar

Dinas Tata Ruang, Cipta Karya dan Perumahan Kota Banjarmasin (2013) Identifikasi Bangunan Rumah Lanting Kota Banjarmasin

https://commons.wikimedia.org (diakses 10 Desember 2016)
https://id.wikipedia.org/wiki/Kota_Banjarmasin (diakses 10 Desember 2016)

Mentayani, I. (2016) Identitas Keruangan Tepian Sungai Dan Perubahannya Pada Permukiman Vernakular Di Banjarmasin dalam Seminar Nasional - Semesta Arsitektur Nusantara 4, Malang, 17-18 November 2016

Mentayani, I. (2016) Identitas Dan Eksistensi Permukiman Tepi Sungai Di Banjarmasin dalam Seminar Nasional Universitas Lambung Mangkurat, Potensi, Peluang, dan Tantangan Pengelolaan Lingkungan Lahan Basah secara Berkelanjutan, Banjarmasin, 5 November 2016

Mentayani, I. (2010) Tipomorfologi Rumah Di Atas Air (Lanting) Di Kalimantan Selatan Dengan Pendekatan Case Study Research dalam Seminar Nasional "Metodologi Riset Dalam Arsitektur, Juni 2010

Mentayani, I. \& Prayitno, B. Arsitektur Tepian Sungai Potret Life Style Masyarakat di Kota Banjarmasin dalam Seminar Nasional Dan Workshop : Life Style And Architecture. Univ Atmajaya, Yogyakarta, 31 Mei 2011.

Rahman, M. (2014) Pelestarian Rumah Lanting Berlandaskan Budaya Sungai Masyarakat Kota Banjarmasin. E-Journal Graduate Unpar. Vol. 1, No.2

Toding, J. B., Kindangen, J. I. \& Sangkertadi (2014) Kenyamanan Termal Pada Rumah Tepi Sungai "Studi Kasus Rumah Tepi Sungai Kahayan Di Kota Palangka Raya" Jurnal Media Matrasain Volume 11, No.3, November 2014 